"An evaluation of a public relations program in promoting synergistic cooperation between schools and industries"

\begin{tabular}{|c|c|}
\hline AUTHORS & $\begin{array}{l}\text { Suranto Aw D https://orcid.org/0000-0002-7338-8689 } \\
\text { R http://www.researcherid.com/rid/Y-2270-2018 }\end{array}$ \\
\hline ARTICLE INFO & $\begin{array}{l}\text { Suranto Aw (2018). An evaluation of a public relations program in promoting } \\
\text { synergistic cooperation between schools and industries. Problems and } \\
\text { Perspectives in Management, 16(4), 353-364. doi:10.21511/ppm.16(4).2018.29 }\end{array}$ \\
\hline DOI & http://dx.doi.org/10.21511/ppm.16(4).2018.29 \\
\hline RELEASED ON & Tuesday, 11 December 2018 \\
\hline RECEIVED ON & Wednesday, 19 September 2018 \\
\hline \multirow[t]{2}{*}{ ACCEPTED ON } & Monday, 03 December 2018 \\
\hline & $(\mathrm{cc}) \mathrm{EY}^{\mathrm{EY}}$ \\
\hline LICENSE & $\begin{array}{l}\text { This work is licensed under a Creative Commons Attribution } 4.0 \text { International } \\
\text { License }\end{array}$ \\
\hline JOURNAL & "Problems and Perspectives in Management" \\
\hline ISSN PRINT & $1727-7051$ \\
\hline ISSN ONLINE & $1810-5467$ \\
\hline PUBLISHER & LLC "Consulting Publishing Company "Business Perspectives" \\
\hline FOUNDER & LLC "Consulting Publishing Company "Business Perspectives" \\
\hline & 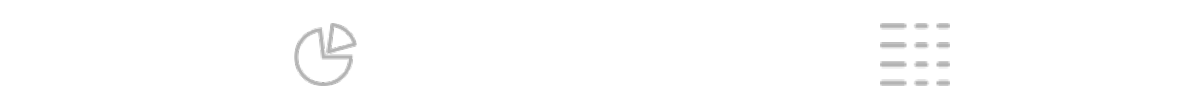 \\
\hline NUMBER OF REFERENCES & NUMBER OF FIGURES \\
\hline 36 & 3 \\
\hline
\end{tabular}

(C) The author(s) 2023. This publication is an open access article. 


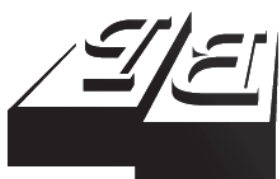

BUSINESS PERSPECTIVES

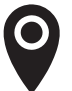

LLC "CPC "Business Perspectives" Hryhorii Skovoroda lane, 10, Sumy, 40022, Ukraine

www.businessperspectives.org

Received on: $19^{\text {th }}$ of September, 2018 Accepted on: $3^{\text {rd }}$ of December, 2018

(C) Suranto Aw, 2018

Suranto Aw, Dr. Assistant Professor of Educational Communication, Faculty of Social Sciences, Yogyakarta State University.

\title{
AN EVALUATION OF A PUBLIC RELATIONS PROGRAM IN PROMOTING SYNERGISTIC COOPERATION BETWEEN SCHOOLS AND INDUSTRIES
}

\begin{abstract}
This evaluation study responds to the need for public relations (PR) as a management function in building and maintaining reciprocal relationships between schools and in dustries that are increasing dramatically. The rapid development of public relations in Indonesia is influenced by socio-cultural changes in Indonesian society, which cannot be separated from the high intensity of national development. This evaluation research aims to compare the actual implementation of a PR program to its intended objectives in promoting cooperation between schools and industries. This study used the Discrepancy Evaluation Model (DEM) with four systematic stages: (1) definition, (2) installation, (3) process, and (4) product. The finding shows that there is no discrepancy between the program's actual implementation and its predetermined objectives. The program implementation has met the criteria of success in achieving proposed goals (good category) and the program operates as it was planned. The program aimed to foster successful collaboration between schools and industries. The scope of the partnership includes information sharing for the purposes of curriculum development, student apprenticeship and competency tests.
\end{abstract}

\section{Keywords}

\section{JEL Classification}

\section{INTRODUCTION}

One of the problems in vocational high school (VHS) in Indonesia recently is the lack of skill conformity between the competencies of graduates and those required by industries, while skill is an important attribute making a worker employable in a decent job (Narayanan \& Nandi, 2017). It has been understood that the Indonesia unemployment rate is still somewhat high. A high unemployment rate indicates that labor resources are not being used efficiently. Growth of unemployment rate in Indonesia itself tends to decrease in the last 10 years, with unemployment rate in 2006 amounting to 10.28 percent, unemployment rate continuing to decline to 7.14 percent in 2010. Although in 2011 it rose to 7.48 percent, in the next year, the unemployment rate declined until 2015 with a value of 6.18 percent (Muryani \& Pamungkas, 2018). Based on these data, most of the jobless people in the country are high school graduates, including VHS's.

Kadir et al. (2016) found that labor productivity of VHS graduates in Indonesia is further hampered by the wide skills gap between the skills attained through formal education and those needed at the workplace. In fact, Indonesia's labor productivity lags behind that of Malaysia, Thailand, the Philippines and China. Consequently, foreign labor market because of excess demand for labor may easily filled by foreign workers (Abdullah et al., 2016). Ama (2008) mentions reasons 
given for lack of employment of the graduates range from lack of experience, communication skills, creative, analytical and critical thinking skills to job mismatch, issue of education and versatility of the graduates. The causes of graduate unemployment in are complex, and both demand and supply factors are at play (Broecke, 2013).

Various efforts to achieve quality vocational education graduates in accordance with the demands of industries have been done by VHSs. One of them is through public relations (PR) programs. PR programs are aimed to establish a synergistic cooperation between schools and industries. In its implementation, PR programs are coordinated by a vice principal on public relations. One of its objectives is to foster good communication and harmonious cooperation between schools and industries. Such communication has been established since the curriculum development process so that schools can produce competent graduates as the industry needed.

The current phenomenon shows an increase in organizational awareness to foster harmonious relations with the public. Moore (2015) states that PR has experienced an amazing development, in which it becomes important force in business, professional, government and educational institutions. Furthermore, Moore (2015) explains that PR plays many roles, including: (1) distributing information to the public; (2) obtaining support through synergistic collaboration with other institutions and the public; (3) getting information dealing with public responses; (5) developing understanding with various partner institutions.

The role of public relations is no longer limited to provide information services, but it becomes wider and more diverse. Formerly, PR practitioners were known as spokespeople for leaders/managers. But, due to the development in many aspects, public relations practitioners are required to have competences of managing information and communication to promote cooperation with the public. PR practitioners are expected to have the ability to work professionally and equipped with adequate knowledge, attitudes and skills, which are relevant to the required qualifications and competencies for their occupations.

This research aims to evaluate whether the implementation of PR programs in vocational schools best suits to PR's objectives in promoting collaboration between schools and industries. The role of PR for an institution is so important that its performance quality needs to be maintained. If its performance can be maintained properly, the works carried out by the institution will be satisfactory. To realize this, an evaluation to get the latest information describing PR performance is required. The evaluation may function that if the discrepancy between the implementation of PR performance and the predetermined targets or goals is found, an appropriate solution can be taken.

\section{LITERATURE REVIEW}

\subsection{Public relations support}

Public relations activity is an option for an organization to support harmonious relationships with the community and other organizations (Gruning, 2017; Moore, 2015; Wilcox \& Nolte, 1997; Gregory, 2004). This theory stresses that in order to achieve the goals of public relations, symmetrical understanding between the parties that collaborate is required. In addition, social exchange theory explains that collaborations will be harmonious, if all parties get benefits. When an organization fails to get benefit from the collaboration process, the or- ganization will resign. Stafford (2008) adds that individuals attempt to maximize their rewards and minimize their costs. When individuals receive rewards from others, they feel a sense of obligation. Grunig and Hunt (1984) explain that PR is an infant scholarly field, although it has been practiced for at least 100 years and perhaps for thousands, depending on how tightly we define the origins of the field. The mindset of the public regarding PR is still very simple. $\mathrm{PR}$ is seen as a communication activity to fight the interests of the organization. Roughly described, the dominant mindset defines public relations as the manipulation of public behavior for the benefit of the manipulated publics, as well as the sponsoring organizations. 
Essentially, PR is a particular field or function, which is required by any company, organization, or institution to foster good relations with its public (public relations). PR is considered as a method that the organization uses to maintain the credibility, products, services or staff with the aim of obtaining recognition and support (Gilaninial et al., 2013). For public relations, other words and expressions are also used: public relations is vital artery and permanent and brain and engine of organization, public relations are the art and social science of that link of intra- and extra-organization together. Meanwhile, Jefkins (2002) argues that public relations are the creation of public understanding through knowledge, and through which positive impact is expected to appear. Moore $(2005$, p. 6$)$ urges that public relations carry out a program to gain public understanding and acceptance.

Furthermore, PR plays a role in decision making, as noted by Wilcox and Nolte (1997), "The value of PR in the influence business decision-making on a daily basis in a variety of for-profit and notfor-profit organizations and situations". Rubin et al. (1994) argue the issue of exploring the importance of communication between the organization and the public to achieve the organization goals. Macmilllan, Money, and Downing (2000) also emphasize the importance of communication between individual and organizations to maintain good business relationship, so they developed a general model, which can be utilized by managers to evaluate whether their relationship with public is strong or not. One of the tasks of PR is to inform various risks to the community. Hayenhjelm (2006) implicitly revealed that risk communication can be defined in two different ways. It can either be defined in terms of dissemination of information about risks, as a one-way communication, or in terms of an "interactive process of information and opinion among individual, groups, and institution (Hayenhjelm, 2006).

\subsection{Synergistic cooperation}

Synergistic cooperation between schools and industries is built with mutual respect. Wilcox and Nolte (1997) observed that despite the continued tension between public relations professional and work place, the symbiosis in the relationship requires that a solid working relationship is based on respect for each other's work. Holladay and Coombs (1993) explained that a proper way for delivering messages is very important for an effective public relation. Selecting the most appropriate language for the message, choosing the best way for presenting the message, and selecting how the message was delivered are also important.

The problem in communication arises from the disturbances or barriers in the transmission, either by the leader or by the receiver. Luthra and Dahiya (2015) mention that the barriers affecting a good and effective communication are lack of planning and purpose before communicating, planning without keeping in mind the nature of audiences, inappropriate tools and techniques, wrong language as a communication medium, lack of trust to each other and disrespect, ignoring the feedback, wrong assumption about listener, lack of self-confidence, values, courage, and knowledge, lack of major leadership qualities and inability to adapt to changes.

\subsection{Program evaluation}

Ideally, every PR program needs to be evaluated to determine the success of its implementation in accordance with the intended purpose. Evaluation is needed to determine the success of PR programs, thus providing information that school leaders can use to improve the program implementation in the future. In some literatures (Cullingford, 1997; Ebel \& Frisbie, 1986; Johnson \& Christensen, 2008), the researchers summarize the advantages of the applied evaluation, namely the creation of a method to assess whether the program runs as planned, its outputs match the intended goals, and the information obtained from the evaluation results is used to determine the right alternative in taking a decision.

The evaluation in this study emphasizes the effort to examine the conformity of the implemented public relations program with its predetermined objectives. Stark and Thomas (1994, p. 8) mention "evaluation as the assessment of congruence between performance and objectives or some standard to determine whether discrepancies existed". Besides, the evaluation is also expected to identify 
and discuss various challenges in the program implementation. Kurniawan et al. (2018, p. 106) argue that evaluation can contribute to the policy-making. Noordegraaf, Douglas, Bos, and Klem (2017, p. 389) describe, "Our own evaluation is used as a reflexive case study: not to present findings but to discuss the challenges we faced and the lessons we learned as evaluators". In order to highlight the discussion on the success of the program, van der Knaap (2017, p. 433) suggests, "More specifically, we can distinguish at least three dimensions of success: (1) the fulfillment of a plan - achieving something intended; (2) acknowledgment by others; and (3) social and societal value".

\section{METHODOLOGY}

\subsection{Evaluative research}

This study is an evaluation research intended to describe the success rate of the implementation of public relations programs in promoting an effective cooperation between schools and industries. It employed the Discrepancy Evaluation Model. This model was developed by Provus (1971) to obtain information on whether mismatches between the objectives (criteria) and the implementation of a program exist. The evaluation focuses on discrepancies between the expected goals and the actual implementation of PR programs in promoting cooperation between vocational schools and industries. Thus, the discrepancies become the criterion for evaluating the program implementation. This study has four stages: (1) definition, which examines whether there is a gap between the existing school policy and the definition of objectives to be achieved by the PR program; (2) installation, which includes attempts to identify whether the program planning is in line with the objectives; (3) process, which focuses on the efforts to examine the gap and conformity between the objectives and the program implementation; (4) product, which describes the evaluation results as information for schools to improve the program implementation.

\subsection{Data collection procedure}

Respondents were 5 vice principals for PR affairs and 97 teachers from Office Administration Subject Teacher Association (OASTA) in
Indonesia. Data were collected by a structured interview, documentation, and questionnaire. The structured interview was conducted to collect data from the vice principals, in which the questions were prepared based on the evaluation steps (Baxter \& Braithwaite, 2008). The documentation was done to collect the data related to school policy and purposes of establishing vice principal for PR position. And finally, questionnaires were used to collect data from the teachers.

\subsection{Data analysis procedure}

Data from vice principals were analyzed by using the interactive analysis comprising four stages: (1) data collection, (2) data reduction, (3) data display, and (4) conclusions: drawing/verifying (Miles, Huberman, \& Saldana, 1994, p. 91). Meanwhile, the data from teachers were served on percentage and average. The questionnaire used the 5-point scale of verbal description. The followings are the descriptive techniques used (Rajab, Suryanto, \& Sunyoto, 2015):

1) percentage, which measures the percentage of the frequency of the responses given by the respondents based on the following formula:

$$
P=\frac{F}{N} \cdot 100 \%,
$$

where $P$ - percentage, $F$ - frequency, $N$ number of respondents;

2) mean or average score, which is calculated by using the following formula:

$$
\mu x=\frac{\sum X_{i}}{N},
$$

where $\mu x$ - mean, $\sum$ - sum of the numbers, $X_{i}$-score, $N$ - number of respondents.

3) conversion of quantitative data to qualitative data (see Table 1):

where $\mu X_{i}$ (ideal mean) - (ideal maximum score + ideal minimum score) / 2, $s b$ (ideal standard deviation) - 1/6 (ideal maximum score - ideal minimum score), $X$ - actual score. 
Table 1. Conversion of quantitative data to qualitative data

\begin{tabular}{c|c|c}
\hline Formula & Mean & Category \\
\hline$X>\mu X_{i}+1.8 \cdot s b_{i}$ & $>4.2$ & Very appropriate/very good \\
\hline$\mu X_{i}+0.6 \cdot s b_{i}<X \leq \mu X_{i}+1.8 \cdot s b_{i}$ & $>3.4-4.2$ & Appropriate/good \\
\hline$\mu X_{i}-0.6 \cdot s b_{i}<X \leq \mu X_{i}+0.6 \cdot s b_{i}$ & $>2.6-3.4$ & Neutral/average \\
$\mu X_{i}-1.8 \cdot s b_{i}<X \leq \mu X_{i}+0.6 \cdot s b_{i}$ & $>1.8-2.6$ & Slightly appropriate/poor \\
$X \leq \mu X_{i}-1.8 \cdot s b_{i}$ & $\leq 1.8$ & Absolutely inappropriate/very poor \\
\hline
\end{tabular}

\section{EVALUATION FINDINGS}

The establishment of vice principal for public relations position in VHS can be understood as the school awareness of the importance of developing harmonious relationship with various parties. In accordance with this, a vice principal for public relations has the duty to implement public relations programs. The targets of public relations programs are the internal public, i.e. the school community members, and the external public, i.e. non-school community members who have interest in school.

This evaluation focuses on PR programs in collaborating with industries. The evaluation uses four stages of Discrepancy Evaluation Model (DEM), including: (1) definition, (2) installation, (3) process, and (4) product. The data were obtained from school policy documents and interviews with seven vice principals for public relations.

\subsection{Definition stage}

This stage aims to obtain the information on the conformity data between the objectives of PR programs and the various policies that exist in schools and those of the government. Data were explored from relevant documents and interviews showing that vice principals for $P R$ in VHS carried out the duty to improve harmonious relationship with industries in accordance with the policy. The objectives of schools' PR programs comprise of: (1) communication with industries, (2) harmonizing the relationship with industries, (3) recording industries responses, (4) establishing school image, (5) internalizing industries inputs to curriculum, 6) facilitating student apprenticeship, (7) administering competency test involving industries, (8) developing cooperation with industries, and (9) being recognized by industries.

This study found that schools have already had a vice principal for $\mathrm{PR}$, regulations, budget, industries collaboration, and memorandum of understanding letter, except for cooperation guideline between schools and industries. Schools get a lot of useful information from industries dealing with strategies to improve graduate competencies.

\subsection{Installation stage}

This stage aims at collecting the information related to school planning in realizing the PR' policies and programs. PR programs intend to support the policy on promoting cooperation between schools and the external parties. PR's planning should promote harmonious relationship between schools and industries. Based on the interview, it shows that PR had translated planning into operational and technical activities. These activities were planned to result policies, programs and activities to achieve certain goals. Table 2 shows the relationship among the policies, programs and activities to build synergistic cooperation between schools and industries.

Table 2 indicates that school policy becomes a source of inspiration for planning and developing operational activities. This procedure indicates the existence of school commitment, in which coordination and communication between schools and industries have become a standardized strategic policy. 
Table 2. Policy, program, and activities

\begin{tabular}{l|l}
\hline \multicolumn{1}{c}{ Policy } & \multicolumn{1}{c}{ Improving cooperation with the external sides } \\
\hline Program & $\begin{array}{l}\text { Poblic relations between schools and industries } \\
\text { Commung coordination meetings with industries } \\
\text { Paying a visit to industries to maintain harmonious relationship } \\
\text { Monitoring and collecting information and response of industries } \\
\text { Providing information services to build school image } \\
\text { Collecting and following up suggestions for curriculum development based on the needs of industries } \\
\text { Processing permits for field industrial practice in industries } \\
\text { Requesting field industrial practice supervisor to the practitioners } \\
\text { Administering competency test with external examiners from industries } \\
\text { Seeking recognition of industries on the competence of the graduates. } \\
\text { Responding to requests on the provision of manpower according to the needs of industries }\end{array}$ \\
\hline
\end{tabular}

\subsection{Process stage}

This evaluation stage focuses on the program and activity implementation in promoting synergistic cooperation between schools and industries. The analysis of the process stage aims to describe the discrepancy and concordance between the planned objectives and the process of achieving them.

The data show that there is no discrepancy between the implementation process and the objectives. PR programs resemble a solution to school and government policy, namely policy on improving cooperation with the external sides. This cooperation is in accordance with the government policy and the school goals in improving school quality. School have prepared regulations, enacted the vice principal for public relations position, improved the communicative competence and the competence in organizing and disseminating information, and supported the media used for maintaining communication with industries.

To ensure that the process of implementing public relations programs runs well, the management of the school has taken various efforts. They include: (a) supervising the implementation of activities, (b) coordinating with industries, (c) opening the communication process through WhatsApp, and (d) holding regular meetings.

The example of school collaboration with industries is the implementation of internship in industries. Students have the opportunity to practice in the workforce after gaining knowledge through learning at schools. Performing this activity, students get experiences to work in real workplace settings, namely in offices, companies, and industries. Students find that physical aspects of laboratory facilities in their schools are very different from that of the actual workspace. Students find real non-physical aspect such as a social environment, which involves human interactions in the internship program. The social interaction at schools is very different from that of in the workplace. Interaction at schools is dominated by interactions between students and their classmates or students and their teachers. Meanwhile, interaction in the workplace is dominated by interactions between employees.

\subsection{Product stage}

This evaluation stage intends to describe how well the program objectives are achieved. The criteria for this are described by the results of the descriptive analysis of quantitative data converted into qualitative ones with the 5 -scale categories. The program objectives are categorized as achieved if the mean score ranges from $>3.4$ to 4.2 (appropriate/good category).

Based on these criteria, the results described in Table 3 with the total mean of 4.05 indicates that the objectives are achieved with the appropriate/ good category, or achieved as planned.

Table 3. The description of the program objectives achievement

\begin{tabular}{|c|c|c|}
\hline No. & Evaluation aspects & Mean \\
\hline 1 & $\begin{array}{l}\text { The establishment of communication and } \\
\text { cooperation with industries }\end{array}$ & 4.89 \\
\hline 2 & The maintainance of synergistic relationship & 4.46 \\
\hline 3 & The establishment of school positive image & 4.00 \\
\hline 4 & $\begin{array}{l}\text { Obtaining suggestions for curriculum } \\
\text { development }\end{array}$ & 3.78 \\
\hline 5 & $\begin{array}{l}\text { The implementation of field industrial } \\
\text { practice and competency test }\end{array}$ & 3.96 \\
\hline 6 & $\begin{array}{l}\text { The recognition of industries on the graduate } \\
\text { competence }\end{array}$ & 3.24 \\
\hline & Total mean & 4.05 \\
\hline
\end{tabular}


The result shows that the evaluation aspect with the highest mean is the establishment of communication and cooperation with industries, with a mean of 4.89 , or in very good category (> 4.2). It indicates that the actual implementation of the program matches with its objectives. Besides, the aspect of the recognition of industries on the graduate competence achieves a mean of 3.24 , or in the neutral/average category $(>2.6-3.4)$. This means that the recognition of industries on the graduate competences is still far from being good (unoptimal).

\section{DISCUSSION}

Program evaluation is a way to gather information on the success of program implementation. The information is used as one of the considerations for improving the institution's quality, performance, and productivity in implementing its programs. In relation to this, Worthen and Sanders (1981, p. 1) state that evaluation is an effort to seek something of worth. That worth thing is information on a program, product, or other alternative procedure. Further, Royse, Thyer, and Padgett (2010, p. 12) emphasize that evaluation functions as a managerial process applied to obtain information referred in the decision making. In line with this, Olatoye and Aanu (2015) assert that evaluation acts as an information gathering process on the achievement of program objectives, its analysis, and the assessment on its effectiveness, whilst Sanders and Sullins (2006) affirm, "evaluation is the process of systematically determining the quality of a program and how it can be improved".

The evaluation findings indicate that institutionalizing the position of vice principal for public relations is expected to improve the synergic collaboration between schools and industries. This policy is intended to overcome the problems dealing with the lack of communication between schools and industries. Therefore, this PR program is expected to smooth the process of information exchange. The theory of information seeking from Donohew and Tipton (2002) explains that the activities of searching, avoiding, and processing information are carried out carefully to act as individuals or organizations that are empowered to obtain the required information and avoid in- formation, which is not relevant with the image of reality. Supporting the above views, McQuail (2006) points out that the availability of cellular technology-based communication media may improve the efficiency in producing and distributing information. Based on this theory, every organization is required to be empowered in processing information. Not like a vessel that only holds information, but the ability to sort and process information is required.

Some literature that discusses the theory of community development (Scott, 2012; Touraine, 1978; Castells, 1996) states that the development stage of today's society has entered the era of information society, especially virtual or digital information. Labeling digital information era highlights the high role played by digital information in all fields in people's daily lives. The development of digital communication has placed information as one of the primary needs and as a commodity that can be traded both in personal and organizational life. Based on this view, public relations activities require innovative strategies to utilize various means and media so that the process of information exchange between schools, the industries, and society can be improved. Innovation is needed to renew activities which have been running. Sulistiawan et al. (2017) argue that the quality of relationships with organization will enhance employee's belief that innovation will bring higher performance.

The findings of this research also reveal that the PR programs designed by the schools are relevant to the policy and are supported by the regulatory system. Utilizing the programs that have been formulated, the school strives to foster synergic collaboration with the industries. This is relevant to Grunig's (2017) theory, which states that public relations activity is an option for an organization to support harmonious relationships with the community and other organizations.

The dominant factor in determining the success of a PR program is the quality of the program itself. According to Cox (2006), the quality of public relations program is comprised of three elements, namely materials (and equipment), activities, and people. Based on this view, the quality of public relations programs depends on the existing facili- 


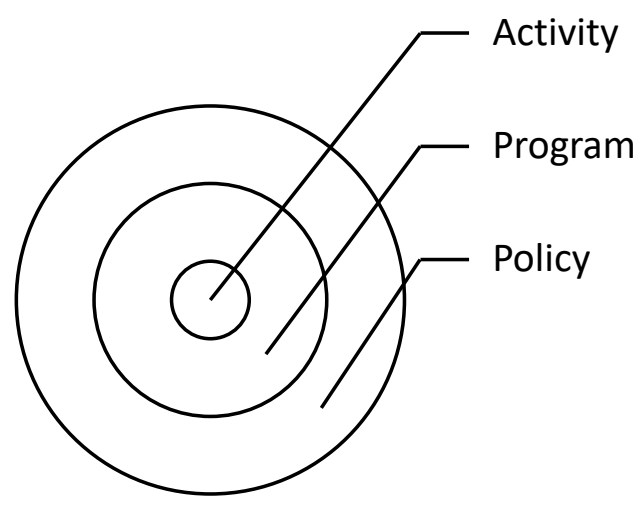

Figure 1. The relationship among the policy, program, and activity

ties and infrastructure, the activities of public relations practitioners, the industries as partners in public relations activities, and all the personnel involved in the activity. In line with this, the quality of public relations programs to promote synergic collaboration between schools and industries will be better if it involves qualified PR practitioners (having competence in their fields), is supported by a quality of industries (having a good attitude to participate in collaboration), and is supported by adequate facilities and infrastructure, both in terms of availability and utility.

The results show that PR programs successfully foster the collaboration with industries. In other words, there is no serious discrepancy between the actual program implementation and its predetermined objectives. The program implementation was supported by both the school and government policy, namely improving cooperation with the external sides. The policy features a set of concepts, decisions, regulations referred to as references on the implementation of either work or leadership programs in school. Moreover, Webster (1997, p. 6) states that "policy is the wisdom in the management affairs, also definite course or methods of action selected to guide and determine present and future decisions".

To support the policy, a public relations program is applied. A program is a series of planned and systemized activities to achieve certain objectives. Fitzpatrick et al. (2011, p. 8) elaborate the program definition and characteristic completely and in detail as follows. A program is a set of planned systematic activities using managed resources to achieve specified goals related to specific needs of specific, identified, participating human individuals or groups in specific contexts resulting in documentable outputs, outcomes, and impacts following assumed (explicit or implicit) systems or beliefs (Fitzpatrick et al., 2011, p. 8).

Policy functions as a resource for the management to formulate the work plans. Consequently, the work plans should be in line with the policy. In other words in order to implement the policy, various programs should be actualized. They should be implemented through activities or projects. Figure 1 illustrates the relationship among policy, program, and activity

In the Indonesian context, the quality of education is measured through its graduates' quality. Quality schools are those whose graduates possess profound knowledge, competence, and personality to compete with others. VHS graduates are also intended to be productive individuals who are capable of working as middle-class workforce and/ or self-employed entrepreneurs who are prepared to take part in the competition. Recently VHS has been appealing to most of the community members, especially those participating intensively in industries, provided that the graduates of vocational education do have the qualifications as (candidate) workers who have certain vocational skills in accordance with their skills.

Zhang (2009) argues that VHS graduates are targeted at mastering practical application skills of students, with both property of higher education (success in school/technical) and property of vocational technique (success in work/behavioral). The fundamental characteristics of vocational-techni- 


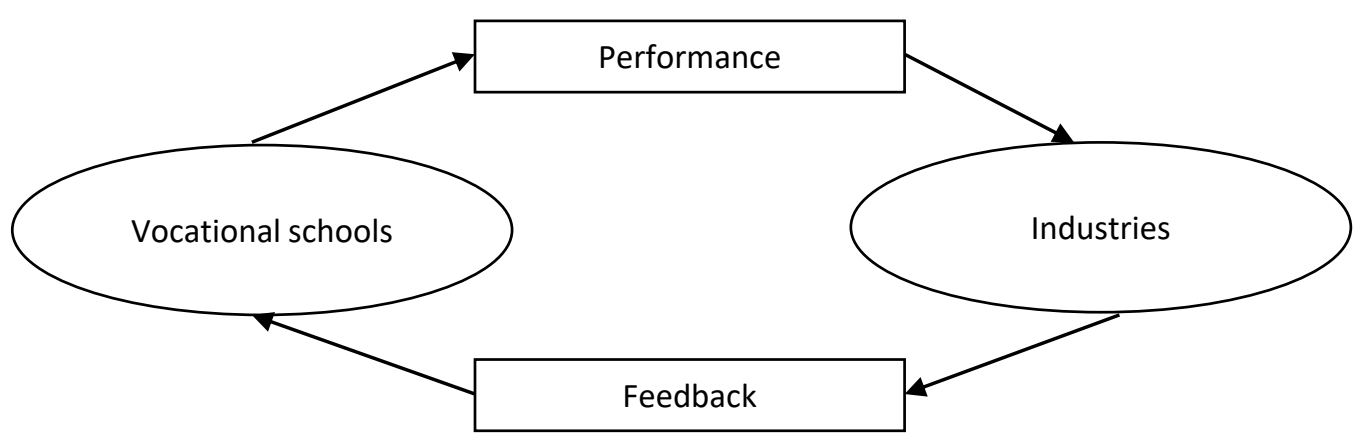

Figure 2. The reciprocal relationship between vocational schools and industries

cal schools should be not to pursue system aticness and completeness of theory, but to emphasize integrity and practicability of practical capacity. Further, students from vocational-technical schools should place extra emphasis on basic competence and skills required for practice in technical fields in their majors, with the precondition that they grasp requisite basic theoretical knowledge and professional knowledge. It implies that the first criterion comprises students' learning achievement in meeting the curricular demands that have been oriented to the demands of industries, while the second criterion includes the students' achievement in acquiring the competencies after experiencing the real work. Chen $(2010$, p. 205) introduces an integrative evaluation model based on a bottom-up approach to validity. This approach more reflects the evaluation of stakeholders in the actual employment. Chen (2010, p. 205) introduces an integrative evaluation model based on the bottom-up approach to validity. This approach more reflects the evaluation of stakeholders in industries.

The efforts to achieve the standards are based on the curriculum developed by the principles of its conformity with the needs of the stakeholders. The government has implemented the "Link and Match" program, which aims to improve the relevance of vocational education to the demands of industries. The program has been implemented through the "Dual System Education" (DSE) format, which provides students with vocational education theories and concepts in schools, and practices for them in industries. The main purpose of the DSE program is to prepare students, as well as enable them to be accepted in industries.

By having field industrial practice, students will acquire direct and authentic experience on the ins and outs of working in the industrial world. Furthermore, the government also implements the Competency Test that involves assessors from external parties or from industries. Active participation from the external parties as assessors and verifiers is expected to actualize strategic steps in creating quality assurance (QA) and quality control (QC) processes in the testing system in vocational secondary education. Thus, such external involvement is the school commitment to being evaluated by the external parties in order to develop the scope of learning in VHS leading to the competence demanded by industries. In addition, in essence, this is the recognition of industries to the competencies of vocational students.

Based on the explanation above, it can be summarized that the collaboration between vocational schools and industries has a reciprocal relationship. In this case, the school obtains information regarding the graduate competencies required by the industries as a basis for developing the curriculum. Implementing this curriculum, schools prepare their graduates in order that they are able to perform the competencies/skills that are relevant to the needs of the workforce. On the other hand, the industries get benefits from recruiting prospective workers who have the desired competence. If a gap still exists, the industries may provide feedback. In addition, whenever the required competency is changing due to the development of competency standards needed by industries, the workforce should immediately provide feedback to the schools. In simple terms, the reciprocal relationship between vocational schools and industries is presented in Figure 2.

Realizing that the PR program for collaboration between schools and industries has a very stra- 
tegic goal, an evaluation is performed. This evaluation study produces information that shows whether a gap between the objectives and implementation of the program exists. The results of this study are expected to be used as consideration for stakeholders in making policy. With regard to this, Stufflebeam and Shinkfield (1985) state that evaluation is the process of delineating, obtaining, and providing descriptive and judgmental information about the worth and accuracy of objects' goals, design, implementation, and impact in order to guide decision making, serve needs, for accountability, and promote understanding of the involved phenomena.

\section{CONCLUSION}

The main objective of this study is to reveal the suitability between the implementation and the goal of the public relations program in fostering collaboration between schools and industries. The method used in this research is a discrepancy evaluation with four components: (1) definition, (2) installation, (3) process, and (4) product. The results of the evaluation show that the implementation of the program has met the criteria of success in achieving the formulated goals, indicated with a total mean score of 4.05 on a 5.0 scale. This finding tells that the achievement of programs to meet the objectives is in a good category, or in accordance with the program objectives.

By referring to the evaluation findings and discussion, this study successfully presents that there is no discrepancy between public relations programs implementation and its objectives. In other words, it can be concluded that the program implementation has met the criteria of success in achieving its predetermined objectives. The porgram aims at promoting cooperation between schools and industries. The cooperation comprises information sharing in respect of curriculum development, the implementation of field industrial practice and competency test, and the recognition of industries for the competencies of the vocational school graduates.

There are two limitations in this study. First, the respondents in this study were the vice principal for public relations and teachers who involved in an Office Administration Subject Teacher Association (MGMP). The study did not involve teachers from other fields of expertise. For further research, it is suggested to take research subjects from other vocational fields of expertise, especially technology expertise. Second, the evaluation model used in this study is discrepancy evaluation, a simple method to see the suitability or incompatibility between objectives and program implementation. This study recommends that the next evaluation research may use different models, such as the CIPP model.

Referring to the conclusion, this study suggests that schools should increase their commitment in the implementation of public relations programs to foster cooperation with industries. This effort intends to obtain complete and rapid information on the dynamics of needs in industries to be immediately responded by the schools.

\section{REFERENCES}

1. Abdullah, H., Abdullah, M. Z., \& Azam, M. (2016). The Impact of Foreign Labour on the Unskilled Labour Demand in Malaysia. Mediterranean Journal of Social Sciences, 7(1), 264-273. http://doi. org/10.5901/mjss.2016.v7n1p264

2. Ama, N. O. (2008, August). Transition From Higher Education To Employment: A Case Study Of Graduates Of Faculty Of Social
Sciences University of Botswana. Educational Research and Review, 3(8), 262-274. Retrieved from http://www.academicjournals. org/app/webroot/article/article1379592851_Ama.pdf

3. Baxter, L. A., \& Braithwaite, D. O. (2008). Engaging Theories in Interpersonal Communication: Multiple Perspectives. Thousand Oaks, California: Sage Publication.
4. Broecke, S. (2013). Tackling Graduate Unemployment in North Africa Through Employment Subsidies: a Look at the SIVP Programme in Tunisia. Broecke IZA. Journal of Labor Policy, 2(9), 1-19. Retrieved from http://adapt.it/adapt-indice-a-z/ wp-content/uploads/2014/09/ iza_tackling_graduate_ unem\%C3\%A8loyment_2013.pdf 
5. Chen, H. T. (2010). The BottomUp Approach to Integrative Validity: A New Perspective for Program Evaluation. Evaluation and Program Planning, 33(3), 205-214. Retrieved from http:// www.unm.edu/ marivera/522\%20 Chen\%20posted\%20readings/bottom\%20up\%20approach\%20integrative $\% 20$ validity $\% 20$ Chen.pdf

6. Cullingford, C. (1997). Assessment versus Evaluation. London: Cassell.

7. Ebel, R. L., \& Frisbie, D. A. (1986). Essential of Educational Measurement. New Jersey: Prentice-Hall, Inc.

8. Fitzpatrick, J. L., Sanders, J. R., \& Worthen, B. R. (2011). Program Evaluation Alternative Approaches And Practical Guidelines. Boston: Pearson.

9. Gilaninial, S., Taleghani, M., \& Mohammadi, M. E. (2013). The Role Of Public Relations In Organization. Arabian Journal of Business and Management Review (Nigerian Chapter), 1(10), 47-51. Retrieved from https:// www.arabianjbmr.com/pdfs/ NG_VOL_1_10/7.pdf

10. Gregory, A. (2004). Public Relations In Practice. London: Sterling VA.

11. Grunig, J. E. (1989). Public Relations Theory. New Jersey: Lawrence Erlbaum Associate Inc. Publisher.

12. Hayenhjelm, M. (2006, February). Asymmetries in risk communication. Risk management journal, 8(1), 1-15. https://doi. org/10.1057/palgrave.rm.8250002

13. Holladay, S. J., \& Coombs, W. T. (1993). Communicating Visions an Exploration of the Role of Delivery in the Creation of Leader Charisma. Management Communication Quarterly, 6(4), 405-427. https://doi.org/10.1177\% 2F0893318993006004003

14. Jefkins, F. (2002). Public relations. Jakarta: Penerbit Erlangga.

15. Johnson, B., \& Christensen, L. (2008). Educational research quantitative, qualitative, and mixed approaches. Los Angeles: SAGE Publications.
16. Kadir, S., Nirwansyah, Bachrul, B. A. (2016). Vocational Education and Technical Training in Indonesia: Challenges and Opportunities for the Future. Retrieved from https://lkyspp.nus. edu.sg/docs/default-source/casestudies/lkysppms_case_study_ technical_and_vocational_education_and_training_in_indonesia. pdf?sfvrsn=e5c5960b_2

17. Kurniawan, T., Muslim, M. A., \& Sakapurnama, E. (2018). Regulatory Impact Assessment And Its Challenges: An Empirical Analysis From Indonesia. Kasetsart Journal of Social Sciences, 39(1), 105-108. https://doi. org/10.1016/j.kjss.2017.12.004

18. Luthra, A., \& Dahiya, R. (2015). Effective Leadership is all About Communicating Effectively: Connecting Leadership and Communication. International Journal of Management \& Business Studies, 5(3), 43-48. Retrieved from https://www.mcgill.ca/ engage/files/engage/effective_leadership_is_all_about_communicating_effectively_luthra_dahiya_2015.pdf

19. Macmillan, K., Money, K., \& Downing, S. (2000). Successful Business Relationship. Journal of General Management, 26(1), 69-83. https://doi.org/10.1177\% 2F030630700002600105

20. Miles, M. B., Huberman, A. M., \& Saldana, J. (1994). Qualitative Data Analysis: A Methods Sourcebook (3rd ed.). Los Angeles: Sage.

21. Moore, H. F. (2015). Public Relations Builds Image With Communication. Bandung: Remaja Rosdakarya.

22. Muryani, \& Pamungkas, P. A. (2018). The Impact of Unemployment Rate, Labor Force, Capital, Inflation Rate, And Government Expenditure on Economic Growth In Indonesia. American Journal of Engineering Research (AJER), 7(3), 109-119. Retrieved from http://www. ajer.org/papers/Vol-7-issue-3/ M0703109119.pdf

23. Narayanan, A., \& Nandi, E. (2017). Do Skilled Workers
Have Decent Jobs? Indian Journal of Human Development, 11(1), 124-132. https://doi. org/10.1177/0973703017715920

24. Noordegraaf, M., Douglas, S., Bos, A., \& Klem, W. (2017). How to Evaluate the Governance Of Transboundary Problems? Assessing A National Counterterrorism Strategy. Evaluation, 23(4), 389-406. Retrieved from https:// journals.sagepub.com/doi/ pdf/10.1177/1356389017733340

25. Olatoye, R. A., \& Aanu, E. M. (2015). Senior Secondary School Science Teachers' Perception Of Using Students To Evaluate Teaching Effectiveness. Journal of Emerging Trends in Educational Research And Policy Studies (JETERAPS), 2(3), 164-170. Retrieved from http://jeteraps. scholarlinkresearch.com/articles/Senior\%20Secondary\%20 School\%20Science\%20Teachers\%20Perception $\% 20$ of $\% 20$ Using\%20Students\%20to\%20 Evaluate\%20Teaching\%20Effectiveness.pdf

26. Provus, M. (1971). Discrepancy Evaluation for Educational Program. Improvement and Assessment. Barkeley: Mc. Cutchen Pu. Corp.

27. Rajab, A., Suryanto, M., \& Sunyoto, A. (2015). Development of Learning Media Applying Basic Analog and Digital Electronics Engineering (Pengembangan Media Pembelajaran Menerapkan Teknik Elektronika Analog dan Digital Dasar). Jurnal Ilmiah Teknologi Informasi, 5(2), 9-17. Retrieved from https://journal. uncp.ac.id/index.php/computare/article/view/165/157

28. Royse, D., Thyer, B. A., \& Padgett, D. K. (2010). Program Evaluation: An Introduction. New York: Springer.

29. Rubin, R. B., Palmgreen, P., \& Sipher, H. E. (1994). Communication Research Measures. New York: The Guilford Press.

30. Sanders, J. R., \& Sullins, C. D. (2006). Evaluation School Programs an Educator's Guide. California: Corwin Press. 
31. Stark, J. S., \& Thomas, A. (1994). Assessment And Program Evaluation. Needham Heights: Simon \& Schuster Custom Publishing.

32. Sulistiawan, J., Herachwati, N. Permatasari, S. D., \& Alfirdaus, Z. (2017). The Antecedents of Innovative Work Behavior: The Roles of Self-Monitoring. Problems and Perspectives in Management 15(4-1), 263-270. https:// doi.org/10.21511/ppm.15(41). 2017.10

33. Van der Knaap, P. (2017). Positive Evaluation And Learning: Looking For 'Success' In Netherlands Road Safety Policy. Evaluation, 23(4), 432-443. https://doi.org /10.1177\%2F1356389017733341

34. Wilcox, D. L., \& Nolte, L. W. (1997). Public Relations: Writing and Media Techniques. New York: Longman.
35. Worthen, B. R., \& Sanders, J. R. (1981). Educational Evaluation: Theory and Practice. Ohio: Charles A. Jones Publishing Company.

36. Zhang, W. (2009, November). Issues of Practical Teaching in Vocational-Technical Schools in China and Their Countermeasures. International Education Studies, 2(4), 75-78. Retrieved from https://files.eric. ed.gov/fulltext/EJ1065766.pdf 